ORGANISATIONAL MATTERS

\title{
Organisational change theory and the use of indicators in general practice
}

\author{
M Rhydderch, G Elwyn, M Marshall, R Grol
}

Qual Saf Health Care 2004;13:213-217. doi: 10.1136/qshc.2003.006536

General practices are making greater use of indicators to help shape and develop organisational arrangements supporting the delivery of health care. Debate continues concerning what exactly such indicators should measure and how they should be used to achieve improvement. Organisational theories can provide an analytical backdrop to inform the design of indicators, critique their construction, and evaluate their use. Systems theory, organisational development, social worlds theory, and complexity theory each has a practical contribution to make to our understanding of how indicators work in prompting quality improvements and why they sometimes don't. This paper argues that systems theory exerts the most influence over the use of indicators. It concludes that a strategic framework for quality improvement should take account of all four theories, recognising the multiple realities that any one approach will fail to reflect.

See end of article for
authors' affiliations
$\ldots \ldots \ldots \ldots \ldots \ldots \ldots \ldots \ldots$
Correspondence to:
Mrs M S Rhydderch,
Department of Primary
Care, The Clinical School,
University of Wales
Swansea, Grove Building,
Singleton Park, Swansea
SA2 8PP; m.rhydderch@
swansea.ac.uk
Accepted
10 February 2004

$\mathrm{T}$ he evidence suggesting that quality problems are caused in part by system failures ${ }^{12}$ has led to an emerging focus on organisational aspects necessary for improving the quality of health care. ${ }^{3-5}$ Performance measurement to raise awareness of existing practice is an important driver of improvement and indicators are one of the tools that have been developed for this purpose. Indicators have been defined as measurement tools "used to monitor and evaluate the quality of important governance, management, clinical and support functions". ${ }^{6}$ Their use is increasingly viewed as an important element of quality improvement programmes in the primary care systems of many countries. ${ }^{78}$

A review of the international literature ${ }^{9}$ has shown that methods to improve organisational aspects generally involve four steps:

- definition of performance criteria;

- development of indicators and methods of assessment;

- practice visits to collect data against indicators;

- feedback to the practice.

Generally, the design of indicators seems to focus on practical issues while theoretical issues and underlying assumptions are seldom made clear.

Van den Hombergh ${ }^{9}{ }^{10}$ was one of the first to develop a valid reliable indicator set with which to assess practice organisation known as the "visit in practice" (VIP) method. This method involves assessment using indicators covering premises and equipment, service and organisation, record keeping, delegation and collaboration, and quality improvement activities. Van den Hombergh's work assumes that a general practice is a system consisting of a number of variables that can be measured by indicators. If he had assumed that general practices were complex organisations, constantly evolving in unpredictable ways, his approach to improving the organisational quality in general practice might have been quite different.

Indicators are more than technical entities: their use to stimulate improvement also relates to concepts and ideas about organisational change. ${ }^{11}$ Examining theories is important in order to consider:

- which aspects of organisation are important to measure;

- how interventions can be best deployed; and

- how to evaluate predictions about the use of indicators.

This paper analyses the literature on organisational change relevant to indicators and documents the practical contribution that can be made to indicators used to improve organisational quality in general practice.

\section{ORGANISATIONAL THEORIES: THE BIG FOUR}

Four theories have been applied to organisational change in general practice: (1) systems, ${ }^{12}{ }^{13}$ (2) organisational development, ${ }^{4}{ }^{14}$ (3) complexity, ${ }^{15}{ }^{16}$ and (4) social worlds. ${ }^{17}$ These map onto a widely accepted typology of organisational change ${ }^{18}$ which suggests four basic types of theory, emphasising goals, people, evolution, and conflict as triggers and mechanisms for change. Although this typology is not exhaustive, it will serve to illustrate the benefits of theoretical analysis.

Reviews of the literature ${ }^{18} 19$ suggest that the following six dimensions reveal differences and similarities between organisational change theories:
- metaphor of organisation
- analytical framework
- trigger for change
- the change process
- the role of leadership
- resistance to change

The four theories will be considered using these six dimensions. A summary is shown in 
table 1. Four studies from primary care, where measurement of organisational aspects is central to improvement, are used to illustrate how measurement is intertwined with the theoretical assumptions (table 2).

Throughout this article "organisational change" refers to the quality improvement process, "theory" refers to a detailed description of organisational characteristics and behaviour specifying the predicted relationships between these and organisational effectiveness, and "framework" refers to key concepts that are relevant to each theory.

\section{DEFINITIONS OF THE FOUR THEORIES Systems theory}

Systems theory emphasises the interrelatedness of parts of an organisation. Improving one part requires that consideration be given to the relationships with other parts of the system. ${ }^{12}$ It is considered equally important to measure organisational aspects such as infrastructure, tasks, technologies and resources (human and financial). ${ }^{13}$ Organisational change can be introduced by altering these variables singly or in combination.

Measuring a range of organisational variables is the focus of the first study (example 1, table 2), based on work with 39 practices in the Netherlands. Geboers et $a l^{20}$ used indicators to measure practice organisation, data management, quality improvement, patient satisfaction, and medical performance. They found that the data gathered could be used to influence district level plans for improvement as well as to stimulate improvement at the practice level.

"Indicators should provide meaningful information which makes it possible to set priorities. Finally the indicators should motivate practices to induce change." (Example 1, table 2) ${ }^{20}$

\section{Organisational development}

Organisational development is defined as a discrete episode of planned change in organisations through the application of behavioural sciences and it therefore emphasises human processes in an organisation. ${ }^{21}$ It assumes that successful organisational change depends on agreement between individual and organisational goals.
Effective team working is a focus for quality improvement in the second study (example 2, table 2). Goni ${ }^{22}$ found evidence to support a relationship between team working variables including empowerment, communication, flexibility and organisational performance in 31 primary health care teams in the Spanish region of Navarrone. He combined indicators of team working, work satisfaction, patient satisfaction, and stakeholder perceptions.

". . . teams are a form of organisational design useful for improving performance in primary health care." (Example 2, table 2$)^{22}$

\section{Complexity theory}

Complexity theory is the study of systems that are characterised by non-linear dynamics. It suggests that practices are complex adaptive systems consisting of local agents whose interactions lead to continually emerging novel behaviour. ${ }^{15}{ }^{16}$ Change emerges as a result of interactions between agents at a local level in the complex system and between the system and its environment. The belief is that efforts to change practice should be preceded by efforts to understand it. The focus is on informally reviewing processes and structures in a way that helps a team to have a sense as to what works well and what could be improved.

The third study is based on work with 18 primary care practices based in Nebraska, USA (example 3, table 2). Crabtree et $a l^{15}$ attempted to understand the practice as an organisation and its relationship to the wider community and health system. The long term aim of this research is to understand how practice characteristics affect preventative service delivery. They do not use indicators, according to the classic definition of indicators, ${ }^{6}$ but rather a range of assessment methods, described in table 2, where the resulting data are interpreted by the practice against benchmarks set by the practice.

"Our study suggests a model and a method for future research in the area of health care process and outcome improvement with practices as collaborators". (Example 3, table 2) ${ }^{15}$

\begin{tabular}{|c|c|c|c|c|}
\hline & Systems & $\begin{array}{l}\text { Organisational } \\
\text { development }\end{array}$ & Complexity & Social worlds \\
\hline & Goals & People & Evolution & Conflict \\
\hline $\begin{array}{l}\text { Metaphor of } \\
\text { organisation }^{19}\end{array}$ & \multicolumn{2}{|c|}{$\begin{array}{l}\text { General practices are inertial and change is } \\
\text { infrequent, discontinuous and intentional }\end{array}$} & \multicolumn{2}{|c|}{$\begin{array}{l}\text { General practices are emergent and self } \\
\text { organising, and change is constant, evolving } \\
\text { and cumulative }\end{array}$} \\
\hline $\begin{array}{l}\text { Analytical } \\
\text { framework }^{19}\end{array}$ & \multicolumn{2}{|c|}{$\begin{array}{l}\text { Change takes place at the level of a single } \\
\text { organisation }\end{array}$} & \multicolumn{2}{|c|}{$\begin{array}{l}\text { Change takes place where the organisation } \\
\text { interacts with another organisation or with } \\
\text { its environment }\end{array}$} \\
\hline $\begin{array}{l}\text { Trigger for } \\
\text { change }^{18}\end{array}$ & $\begin{array}{l}\text { Clear goals, } \\
\text { measurement and } \\
\text { feedback loops }\end{array}$ & $\begin{array}{l}\text { Overlap between } \\
\text { individual and } \\
\text { organisational goals }\end{array}$ & $\begin{array}{l}\text { Desire to try multiple } \\
\text { approaches and let } \\
\text { direction arise } \\
\text { gradually over time }\end{array}$ & Difference of opinion \\
\hline $\begin{array}{l}\text { Change } \\
\text { process }^{18} 19\end{array}$ & $\begin{array}{l}\text { Change as goal } \\
\text { achievement }\end{array}$ & $\begin{array}{l}\text { Change as a } \\
\text { Lewinian process }\end{array}$ & $\begin{array}{l}\text { Change is Confucian, } \\
\text { already under way, } \\
\text { without end }\end{array}$ & $\begin{array}{l}\text { Change as conflict } \\
\text { followed by synthesis } \\
\text { into new order }\end{array}$ \\
\hline Role of leader & $\begin{array}{l}\text { To establish a } \\
\text { measurement and } \\
\text { feedback process }\end{array}$ & $\begin{array}{l}\text { To encourage } \\
\text { participation }\end{array}$ & $\begin{array}{l}\text { To interpret emerging } \\
\text { change with team }\end{array}$ & $\begin{array}{l}\text { To take a strategic } \\
\text { view of multiple } \\
\text { agendas }\end{array}$ \\
\hline $\begin{array}{l}\text { Resistance to } \\
\text { change }\end{array}$ & $\begin{array}{l}\text { Due to data poverty } \\
\text { and lack of clear } \\
\text { goals }\end{array}$ & $\begin{array}{l}\text { When individual } \\
\text { and organisational } \\
\text { goals differ }\end{array}$ & $\begin{array}{l}\text { As one stage in the } \\
\text { sense making process }\end{array}$ & $\begin{array}{l}\text { As a natural part of a } \\
\text { conflict process }\end{array}$ \\
\hline
\end{tabular}


Table 2 Primary care studies in which organisational aspects were assessed

\begin{tabular}{|c|c|c|c|c|}
\hline Reference & Aim and setting & Setting and instruments & $\begin{array}{l}\text { Organisational aspects } \\
\text { reviewed or assessed }\end{array}$ & Main finding \\
\hline $\begin{array}{l}\text { Example 1: } \\
\text { Geboers et afo }\end{array}$ & $\begin{array}{l}\text { To devise a comprehensive } \\
\text { assessment method to measure } \\
\text { the quality of organisation in } \\
\text { general practice } \\
39 \text { practices in the Netherlands }\end{array}$ & $\begin{array}{l}\text { VIP method structured } \\
\text { interview patient } \\
\text { questionnaire practice } \\
\text { self-report }\end{array}$ & $\begin{array}{l}\text { Medical performance } \\
\text { Practice organisation } \\
\text { Data management } \\
\text { Collaboration } \\
\text { Ql activity } \\
\text { Patient satisfaction }\end{array}$ & $\begin{array}{l}\text { The information was useful } \\
\text { both at a district and practice } \\
\text { level. Nearly all practices } \\
\text { started improvement projects } \\
\text { on the basis of assessment }\end{array}$ \\
\hline Example 2: Goni ${ }^{22}$ & $\begin{array}{l}\text { To test whether team working } \\
\text { influenced organisational } \\
\text { performance in primary health } \\
\text { care teams } \\
31 \text { primary health care teams } \\
\text { in Spain }\end{array}$ & $\begin{array}{l}\text { Team working scale } \\
\text { Data envelopment analysis } \\
\text { User questionnaire } \\
\text { Worker questionnaire }\end{array}$ & $\begin{array}{l}\text { Team-goals, empowerment, } \\
\text { communication, flexibility, } \\
\text { recognition and appreciation } \\
\text { Organisation-economy, efficiency, } \\
\text { perceived quality of service, work } \\
\text { satisfaction }\end{array}$ & $\begin{array}{l}\text { Teams are a form of } \\
\text { organisational design useful } \\
\text { for improving performance }\end{array}$ \\
\hline $\begin{array}{l}\text { Example 3: } \\
\text { Crabtree et } a l^{5}\end{array}$ & $\begin{array}{l}\text { To understand the practice as } \\
\text { an organisation and its } \\
\text { relationship to the larger } \\
\text { community and health system } \\
18 \text { practices in the USA }\end{array}$ & $\begin{array}{l}\text { Semi-structured interviews } \\
\text { Note taking by field } \\
\text { researchers } \\
\text { Office documents } \\
\text { Direct observation of } \\
\text { clinical encounters }\end{array}$ & $\begin{array}{l}\text { Features of community, practice, } \\
\text { staff, patients }\end{array}$ & $\begin{array}{l}\text { The complexity of primary } \\
\text { care practices is best } \\
\text { understood from multiple } \\
\text { perspectives }\end{array}$ \\
\hline $\begin{array}{l}\text { Example 4: Campion } \\
\text { Smith and Riddoch }\end{array}$ & $\begin{array}{l}\text { To illustrate how one practice } \\
\text { approached QI by integrating } \\
\text { practice activity such as } \\
\text { education, audit, research, } \\
\text { clinical effectiveness } \\
1 \text { UK practice }\end{array}$ & & $\begin{array}{l}\text { Rapid management of urinary } \\
\text { tract infection } \\
\text { Establishment of a palliative care } \\
\text { register } \\
\text { Changes to prescribing } \\
\text { Establishing a spirometry service } \\
\text { for patients with chronic lung disease } \\
\text { Initiatives to improve patient access }\end{array}$ & $\begin{array}{l}\text { Proactively combining } \\
\text { different agendas such as } \\
\text { education, audit, research } \\
\text { and clinical effectiveness can } \\
\text { facilitate effective quality } \\
\text { improvement in general } \\
\text { practice }\end{array}$ \\
\hline
\end{tabular}

\section{Social worlds theory}

Social worlds theory suggests that change emerges as a function of negotiation and renegotiation between two or more social worlds. ${ }^{17}$ This theory emphasises the importance of considering who is using the indicators and for what purpose. A tension often exists in practices between the activities that a practice believes lead to quality improvement for patients and doing those things that have to be done to satisfy the quality improvement targets. One example of this in the UK is the tension between meeting rising patient expectations and meeting quality standards that have been externally imposed.

\section{KEY DIMENSIONS: SIMILARITIES AND DIFFERENCES BETWEEN THEORIES \\ Metaphor for organisation}

Systems and organisational development theories both view general practices as places where change is planned as an intentional event. These theories assume that the practice moves from one point to another more developed point. Complexity and social worlds theories jointly view general practices as an emergent self-organising system where change is constant, evolving and cumulative, and cannot be so easily predicted.

\section{Analytical framework}

As Huntington argued, most organisational development literature is about change at the level of a single organisation, described as the "micro" level. ${ }^{4}$ It focuses more on individual, group, and organisational behaviour than on inter-organisational behaviours which are referred to as "macro" processes. ${ }^{23}$ Systems theory likewise can be considered micro because it focuses on change in a single unit (small or large).

It is the interaction between the practice and its context or environment that prompts both social worlds and complexity theories to be considered to be more macro than micro. They consider quality improvement in a practice influencing and being influenced by outside forces extending beyond the boundaries of the practice. ${ }^{15} 17$

\section{Trigger for change}

Systems theory suggests that the trigger for change will be a clear, specific, measurable goal. Feedback from an assessment against the standard or goal is the final cause for guiding the movement forward ${ }^{18}$ and will trigger quality improvement.

"The results showed that practices were capable of selecting subjects for improvement on the basis of the assessment." (Example 1, table 2$)^{20}$

Organisational development theory seeks to create change to which people are committed. The trigger for change is overlap between individual and organisational goals.

"To improve teams' efficiency and economy levels, the administration need to design incentives which would bring about a greater commitment by personnel to organisational objectives." (Example 2 , table 2$)^{22}$

Complexity theory views change as an evolution of existing activity rather than being driven by standards and quantitative indicators. In example 3 the study "provided rich data for describing multiple aspects of primary care practice . . fostering collaborative practice change." (Example 3, table 2$)^{15}$

Social worlds theory suggests that conflict is the trigger for change- - a difference of opinion between two distinct social worlds. In the fourth study (example 4, table 2) CampionSmith and Riddoch ${ }^{24}$ described their practice's experience of using a quality improvement approach based on the 1998 Calman report, ${ }^{25}$ suggesting that to improve quality it was essential to achieve "a better alignment of continuing education, audit, research and application of clinical effectiveness materialtogether known as continuing professional development (CPD)." (Example 4, table 2) ${ }^{24}$

\section{The change process}

In systems theory the change process involves setting standards, measuring achievement of standards, and feedback (see example 1, table 2). 
Organisational development theory typically uses Lewin's three-step change model ${ }^{26}$ which involves (1) breaking down old tasks, behaviours and attitudes (unfreezing), (2) a transition time towards new ways of doing things (moving), and (3) the establishment of new routines (refreezing). Goni (example 2, table 2) tested the relationship between team working and organisational performance. Having found partial support for this hypothesis, the "team working" instruments he described could be used as part of a proposed change process by providing feedback. This could make unseen but powerful patterns of behaviours among team members visible to others, thus creating an opportunity to challenge existing practice and discuss how new routines might help improve performance

In complexity theory the change process and outcome is less certain. For practices that have quality improvement as an aim, the change process involves trying out different approaches and moving towards that which seems to be working best. ${ }^{16}$ Crabtree $e t$ al ${ }^{15}$ were prepared for the dynamic interaction between the assessment and change process, open to one influencing the other.

In social worlds theory, again the process for change is less certain. The status quo is challenged by an opposing view representing a new order. Tovey and Adams ${ }^{17}$ noted that there was often a tendency in change projects to look for points where two power agendas are in agreement.

"The practice accepted that negotiation and choice was important. They looked for areas where there was congruence between the practice's aims and those things that had to be done to satisfy the external agenda." (Example 4, table 2) 23 $^{23}$

\section{Leadership and resistance to change}

The nature of resistance to change by individuals and teams influences the role of those in leadership positions: these two dimensions are discussed together.

In systems theory, leadership involves goal setting and the establishment of measurement and feedback loops. Resistance is a consequence of lack of clear goal setting and data poverty.

In organisational development theory, the role of the leader is to encourage participation by individuals and teams. Leader activity is concerned with ensuring overlap between individual and organisational goals. Resistance is due to a lack of overlap between organisational and individual goals.

In complexity theory, as Kernick argued, ${ }^{27}$ the whole process of reviewing and improving practice performance is "important only as a binding mechanism, holding people together just long enough to reflect and make sense of what has happened". Acknowledging the cognitive processes associated with change, leader activity is concerned with helping individuals to interpret emerging change. Resistance is seen as one stage in the sense making process, prompting reflective questions about why change is happening.

Social worlds theory suggests that leadership is strategic in orientation and is about striking a balance between different perspectives. Resistance is viewed as a natural part of a conflict process.

\section{DISCUSSION}

This paper argues that organisational indicators in the context of any health system should be defined by a strategic framework that recognises a place for four different types of quality improvement activity:

- Systems driven improvement based on achieving competence against a clearly defined set of standards for the organisation of general practice that may reflect threshold or superior performance.
- Organisational development driven improvement based on achieving longer term adaptability through effective team working, participative decision making and problem solving.

- Complexity driven improvement based on following a path of continuous modifications as the future unfolds.

- Social worlds driven improvement based on recognising a shifting political and managerial context that determines the balance of investment in each of the above three areas in any given country.

Accreditation or measurement against standards or specific indicators remains the predominant model for improving quality in the primary care system of many countries. This may reflect the social world for healthcare delivery where the focus is increasingly on the standardisation of care, protocol driven decision making, and a culture dominated by risk minimisation. The focus of indicators in systems driven accreditation is on content. This approach has been implemented in health systems where variation in the quality of care has been observed. Defining an indicator set and a measurement and feedback process is both costly and time consuming. The contents of such an approach will, in any case, need to be reviewed and updated in the longer term to reflect changing benchmarks.

Quality improvement driven by organisational development focuses on empowering and involving practice teams in problem solving. This approach is more construct than content driven, describing competence using language such as team working, problem solving, and effective communication. In recent years, accreditation systems have included issues such as effective team working alongside more concrete issues. However, one problem is that the assessment of a construct is more difficult than assessment of a concrete issue. It has to be inferred rather than observed. In addition, many psychometric measures such as the team climate inventory ${ }^{28}$ are not designed to be used in a summative way. Organisational development may be most helpful in educational settings to aid practices going through transition when effective team working is more important than ever.

Adopting a complexity driven approach to improving quality in primary care demands a cultural shift from undertaking discrete projects towards an agreement to embrace continuous organisational learning. Its emphasis on the cognitive processes of individuals and teams that accompany change brings a fresh perspective. However, the price for relevance to a local setting can be the lack of an aggregate picture across a number of practices. The design of an approach where assessment and change process are dynamically interacting makes evaluation by traditional methods futile. This approach may be particularly helpful in identifying newly emerging aspects of organisation that will become the established standards of tomorrow. The needs of the wider health system for aggregated performance management information may be less easily satisfied. For this reason, it may be difficult for this method to gain support in "top down" centrally managed health systems.

The fourth area of the framework suggests that debate about the balance of activity between systems, organisational development, and complexity will be determined by power balance in the quality improvement agenda of the wider health system. The debate about the tensions between accreditation and improvement ${ }^{29}$ can be best understood from this perspective. In addition, it has been argued ${ }^{30}$ that the process for change in the UK is primarily "top down" and that greater encouragement should therefore be given to encouraging ownership of change at the "lower" individual, team and organisational levels. 


\section{Key messages}

- Four theories between them describe quality improvement activity in general practice: systems, organisational development, complexity, and social worlds.

- These emphasise the role of people, goals, conflict, and evolution as drivers for organisational change.

- Systems driven accreditation is the dominant approach to quality improvement in the primary care systems of many countries.

- A strategic framework for quality improvement should achieve a balance of activity by considering five factors: nature of competence, level at which information is required, maturity of health system, centralisation of health system, and existing balance.

\section{Limits of our approach}

We used just four examples to review the potential application of organisational change theories to the design of organisational indicators for quality improvement. The authors of examples 2 and 3 classified their experiences as being organisational development or complexity focused while the authors of examples 1 and 4 did not explicitly mention organisational change theory. We have also neglected to discuss criticisms associated with each theory in detail.

\section{Implications}

The implication for those involved with the use of organisational indicators at policy and practical levels is the need to consider the following factors. They will influence the extent to which the chosen design for indicators is effective in prompting sustained improvements in general practice.

- Is the target organisational activity emerging, transitional, or established?

- At what level is the information to be used-practice, local management, policy levels?

- How mature is the existing health system?

- How centralised is the existing health system?

- What is the balance of quality improvement activity already in existence?

The predominant models for quality improvement in many countries seem to be driven by a systems approach. This is akin to driving through the rear view mirror, analysing what effective general practices already do. This will only serve to "fix" the current way of doing things. ${ }^{31}$ Such systems, although valuable, can potentially create too much "homogeneity", reducing the potential for novel perspectives to emerge. $^{31}$ There is a balance to be struck between this approach and a more futures focused approach, anticipating and making sense of likely changes. This brings the need for educational and values driven approaches built around organisational development and complexity.

In conclusion, the dominant theory underpinning the design and use of indicators of general practice organisation in many countries appears to be systems based. This may be because performance management depends on achieving demonstrable improvement across a number of practices using a common standard. However, people, operating in complex contexts, inhabit general practices. The design and use of indicators needs to acknowledge theoretical frameworks and to recognise the multiple realities that any one approach will fail to reflect.

\section{ACKNOWLEDGEMENTS}

The lead author holds an NHS Research and Development National Primary Care Researcher Development Award and would like to thank Professor Yvonne Carter and Professor Cliff Bailey at the National Coordinating Centre for Research Capacity Development for their encouragement and support.

\section{Authors' affiliations}

M Rhydderch, G Elwyn, Department of Primary Care, The Clinical School, University of Wales Swansea, Swansea SA2 8PP, UK

M Marshall, National Primary Care Research and Development Centre, University of Manchester, Manchester M13 9PL, UK

R Grol, Centre for Quality of Care Research, University of Nijmegen, 6500 HB Nijmegen, The Netherlands

\section{REFERENCES}

1 Institute of Medicine. Crossing the quality chasm: A new health system for the 21 st century. Washington: National Academy Press, 2001.

2 Department of Health. Building a safer NHS for patients: implementing an organisation with a memory. London: The Stationery Office, 2001.

3 Koeck C. Time for organisational development in healthcare organisations. Br J Gen Pract 1998;317:1267-8.

4 Huntington J, Gillam S, Rosen R. Clinical governance in primary care: organisational development for clinical governance. BMJ 2000;321:679-82.

5 Davies HTO, Nutley SM. Developing learning organisations in the new NHS. BMJ 2000;320:998-1000.

6 Joint Commission on Accreditation of Healthcare Organizations (JCAHO). Primer on indicators development and application. Terrace, IL: JCAHO, 1990.

7 Royal New Zealand College of General Practitioners (RNZCGP). Aiming for excellence in general practices: standards for general practice. Auckland: RNZCGP, 2000.

8 Royal College of General Practitioners. Quality and standards. 2003. http:// www.rcgp.org.uk/rcgp/webmaster/quality_and_standards.asp.

9 Van den Hombergh P. Practice visits. Assessing and improving management in general practice. PhD thesis Introduction Nijmegen, NL: WOK, 1998.

10 Van den Hombergh P, Grol R, van den Hoogen HJM, et al. Practice visits as a tool for quality improvement: acceptance and feasibility. Qual Saf Health Care 1999:8:167-71.

11 Sheldon T. Promoting health care quality: what role performance indicators? Qual Saf Health Care 1998;7:45-50.

12 Checkland P. Systems thinking, systems practice. New York: Wiley, 1981.

13 Hellreigel D, Slocum JW, Woodman RW. Organizational behavior. St Paul: West Publishing Company, 1992

14 Garside P. Organisational context for quality: lessons from the fields of organisational development and change management. Qual Health Care 1998;7:8-15.

15 Crabtree BF, Miller WL, Stange KC. Understanding practice from the ground up. J Fam Pract 2001;50:881-7.

16 Plsek PE, Greenhalgh T. The challenge of complexity in healthcare. BMJ 2001;323:625-8

17 Tovey P, Adams J. Primary care as intersecting social worlds. Soc Sci Med 2001;52:695-706.

18 Van de Ven AH, Poole M. Explaining development and change in organisations. Acad Manage Rev 1995:510-40.

19 Weick KE, Quinn RE. Organizational change and development. Annu Rev Psychol 1999;50:361-86.

20 Geboers H, Mokkink H, van Montfort P, et al. Comprehensive assessment of the quality of care in small-scale primary care practices. J Clin Governance 2002;10:51-61.

21 Porras J, Robertson P. Organisation development. In: Dunnette M, Hough L, eds. Handbook of industrial and organisational psychology. Consulting Psychologists Press, 1992.

22 Goni S. An analysis of the effectiveness of Spanish primary health care teams. Health Policy 1999;48:107-17

23 Woodman RW. Organizational change and development: new arenas for inquiry and action. J Manage 1989;15:205-28.

24 Campion-Smith C, Riddoch A. One Dorset practice's experience of using a quality improvement approach to practice professional development planning Br J Gen Pract 2002;52(Suppl):S33-7.

25 Calman K. A review of continuing professional development in general practice. London: Department of Health, 1998.

26 Lewin K. Field theory in social science. New York: Harper Row, 1951.

27 Kernick D. Let them eat quality. Br J Gen Pract 2002;52(Suppl):S48.

28 Anderson NR, West MA. Measuring climate for work group innovation: development and validation of the team climate inventory. J Organisational Behav 1998; 19:235-58

29 Buetow SA, Wellingham J. Accreditation of general practices: challenges and lessons. Qual Saf Health Care 2003;12:129-35.

30 Ferlie $\mathbf{E}$, Shortell SM. Improving The quality of health care in the UK and USA: a framework for change. Millbank Quarterly 2001 ;79(2).

31 Sparrow PR. Organizational competencies. In: Anderson N, Herriot P, eds. Assessment and selection in organizations. Chichester: John Wiley, 1994. 